\title{
A Comparative Study on Behavior of Concrete to Partial Replacement of Cement by Rice Husk Ash and Glass Powder
}

\author{
Mr. Nitin S.Taksande ${ }^{1}$, Mr. G. D. Dhawale ${ }^{2}$, Dr .S. G. Makrande ${ }^{3}$, Mr.M.R.Nikhar ${ }^{4}$ \\ M. Tech Student, Department of Civil Engineering, B.D.College of Engineering, Wardha, India ${ }^{1}$ \\ Professor, Department of Civil Engineering, B.D.College of Engineering, Wardha, India ${ }^{2,3}$ \\ Assistant Professor, Department of Civil Engineering, B.D.College of Engineering, Wardha, India ${ }^{4}$
}

\begin{abstract}
In Civil Engineering 'Cement' plays the important role as it is impossible to produce any sustainable infrastructure without use of cement. We can say everything is incomplete without 'Cement' as construction is the factor which rapidly growing with new innovations and ideas. Rice husk ash (RHA) industrial are a by-product from the burning of rice husk. Rice husk is extremely prevalent in East and South-East Asia because of the rice production in this area. The rich land and tropical climate make for perfect conditions to cultivate rice and is taken advantage by these Asian countries. Therefore the entire rice product is used in an efficient and environmentally friendly approach. In this article we will be exploring the common processes of burning rice husk and the advantages of using the burnt ash in cement to facilitate structural development primarily in the East and South-East Asian regions. We will be investigating prior research from various sources, as well as prepare specimens of our own to perform a range of strength tests. The levels of replacement of cement by rice husk ash, and glass powder are 5\%,10\%,15\% and 20\%. The properties which are determined and compared in this study are workability, 7, 14, 21 and 28 days compressive strength. Pozzolanas are an important ingredient in the production of alternative cementing materials to Portland cement reactive aggregates. Waste glass powder in proper proportion can be used to resist chemical attack. The aim of this project work is to use rice husk ash and glass powder in the range 5\%,10\%,15\% and 20\% of as replacement of cement and concrete cube, cylinder and beam strength compared with conventional concrete cubes, cylinder and beam respectively. The present study investigates the effect of pozzolanic material in concrete and hence improving the strength of concrete. This work evaluates the performance of Rice Husk Ash and glass powder as a partial replacement of cement in concrete. In this project the rice husk ash percentage is with same replacement of glass powder. The strength properties of concrete are compared with the above varying percentage and the result on which it gives maximum strength is found out.
\end{abstract}

Keywords: Compressive Strength, Flexural Strength, Splitting Tensile Strength, Glass Powder

I. INTRODUCTION

Natural resources are of two types- the renewable and the non-renewable. Renewable resources which can be recycled again and again which are utilized for our benefits. But non- renewable resources are those, which once removed and utilized are lost forever. The major problem facing by mankind today is about the utilization of natural resources in order to meet the human needs and maintain the economic growth without exhausting the resources and endangering the environmental integral on which life economic prosperity and our security depend. The worldwide utilization of regular sand is high because of the broad utilization of cement. Specifically, the interest for regular sand is high in creating nations inferable from quick infrastructural development, buildings and different structures since cement assumes the critical part and a substantial quantum of its being used. Concrete is the $2^{\text {nd }}$ largest of the most widely used materials; but there are environmental issues associated with its use which are needed to be taken under consideration and cannot be ignored. Concrete production uses large quantities of natural resources as aggregates and contributes to the release of carbon dioxide during the production of cement. One ton of carbon dioxide is released into the atmosphere for the production of one ton of cement, which is approximately 7\% of the world's total yearly production of $\mathrm{CO} 2$ (Meyer, 2004). Concrete is a common construction material in India and its production causes the same environmental concerns as that of regular concrete. In recent years, there has been an increasing incentive to minimize the environmental effect of the construction industry through programs such as the Leadership in Energy and Environmental Design (LEED) Green Building Rating System, which rewards points for sustainable construction practices (Ca GBC, 2009). Greater sustainability of the construction industry can be achieved if a portion of the virgin aggregate or cement is replaced with waste materials. Significant experimental work were performed on the use of recycled concrete aggregate to replace virgin aggregate and on the use of pozzolanic materials to be used as partial 


\title{
International Advanced Research Journal in Science, Engineering and Technology
}

\author{
Vol. 6, Issue 4, April 2019
}

replacement of cement in concrete, such as fly ash, silica fume and ground granulated blast furnace slag. Due to the successful implementation of these waste materials into regular concrete there is increased desire to find new postconsumer materials which can be used as a partial replacement for cement.

The experimental work presented in this research looks at the use of glass and rice husk ash, as an eco-friendly material to replace cement in the production of concrete.

\section{MATERIALS}

Following materials are used in present study

$\begin{array}{ll}\text { - } & \text { Cement } \\ \text { - } & \text { Sand } \\ \text { - } & \text { Aggregate } \\ \text { - } & \text { Water } \\ \text { - } & \text { Glass Powder } \\ \text { Rice Husk Ash }\end{array}$

\section{Cement}

Hydraulic cement made by finely pulverizing the clinker produced by calcining to incipient fusion a mixture of argillaceous and calcareous materials Portland cement is the fine gray powder that is the active ingredient in concrete. For present study 43 grade OPC was used.

\section{Sand}

River sand is a widely used construction material all over the world, especially in the production of concrete, cementsand mortar and concrete blocks. Sand is a naturally occurring granular material composed of finely divided rock and mineral particles. The composition of sand varies, depending on the local rock sources and conditions, but the most common constituent of sand in inland continental settings and non-tropical coastal settings is silica (silicon dioxide, or $\mathrm{SiO}$ ), usually in the form of quartz. Locally available river sand was used in present study.

\section{Aggregate}

In addition to cement, water and aggregates are the other primary constituents of concrete mixtures. Aggregate is a rocklike material of various sizes and shapes, used in the manufacture of Portland cement concrete, bituminous (asphalt) concrete plaster, grout, filter beds, and so on. The ASTM standards ( C125 and D8 ) define aggregate as a granular material such as sand, gravel, crushed stone, or iron- blast furnace slag used with a cementing medium to form mortar or concrete, or alone as in base course or railroad ballast.

\section{Water}

Potable water was used in this study. Water is a crucial component of concrete as it is viably included in chemical responses with cement, particularly hydration. In the present examination consumable water is used according to IS 456: 2000 was used for preparation of cement, the water concrete proportion chooses the quality of cement.

\section{Glass Powder}

Waste glass available locally was collected and made into glass powder. Glass waste is very hard material. Before adding glass powder in the concrete it has to be powdered to desired size. Glass is an inert material which could be recycled and used many times without changing its chemical Property. We will crash waste flat glass and prepare it as a powder to be used as cementitous or filler material in concrete mixes. Glass is an amorphous material with high silica content making it potentially pozzolanic when particle size is less than $150 \mu \mathrm{m}$.

Table 2.1 Chemical properties of Glass Powder

\begin{tabular}{|c|c|}
\hline $\begin{array}{c}\text { Chemical Properties of Glass } \\
\text { Powder Oxides }\end{array}$ & $\begin{array}{c}\text { Oxides Present In Glass } \\
\text { Powder }(\boldsymbol{\%})\end{array}$ \\
\hline $\mathrm{CaO}$ & 11.42 \\
\hline $\mathrm{SiO} 2$ & 72.61 \\
\hline $\mathrm{Al} 2 \mathrm{O} 3$ & 1.38 \\
\hline $\mathrm{Fe} 2 \mathrm{O} 3$ & 9.70 \\
\hline $\mathrm{MgO}$ & 0.79 \\
\hline $\mathrm{Na} 2 \mathrm{O}$ & 13.7 \\
\hline $\mathrm{K} 2 \mathrm{O}$ & 0.43 \\
\hline
\end{tabular}




\section{International Advanced Research Journal in Science, Engineering and Technology}

Vol. 6, Issue 4, April 2019

Table no.2.2 Chemical constituents of RHA

\begin{tabular}{|c|c|c|c|}
\hline Constituents & & Percentage & \\
\hline & Mehta & Zhang & Bui \\
\hline Silica (SiO2) & 87.2 & 87.3 & 86.98 \\
\hline Alumina (A12O3) & 0.15 & 0.15 & 0.84 \\
\hline Iron Oxide (Fe2O3) & 0.16 & 0.16 & 0.73 \\
\hline Calcium Oxide (CaO) & 0.55 & 0.55 & 1.40 \\
\hline Magnesium Oxide (MgO & 0.35 & 0.35 & 0.57 \\
\hline Sodium Oxide (Na2O) & 1.12 & 1.12 & 0.11 \\
\hline Potassium Oxide (K2O) & 3.68 & 3.68 & 2.46 \\
\hline Sulfur Oxide (SO3) & 0.24 & 0.24 & - \\
\hline
\end{tabular}

III.

\section{METHODOLOGY}

In this experimental investigation an attempt has been made to find out the strength of concrete produced by replacing the cement with Rice husk ash \& waste glass powder in various percentages ranging from 5\% to $20 \%$ in increments of $5 \%[0 \%, 5 \%, 10 \%, 15 \%$, and 20\%,]. Ordinary Portland Cement (OPC) 43 grade, locally available sand and coarse aggregates were used in this experiments. The sand used was a Zone II had the specific gravity 2.6. The specific gravity of the coarse aggregate was 2.59 . The coarse aggregate used were of $12 \mathrm{~mm}$ and down size. The glass powder was obtained by crushing waste glass pieces in a wardha market. The 150 micron passing fraction was used for the experimentation. Mix design carried out for M25 as per IS 10262:2009 yielded a mix proportion of 1: 1.55: 3.02 with water cement ratio of 0.45 . Specimens were prepared according to the mix proportion and by replacing cement with glass powder in different proportion and use of sand. An increasing trend in compressive strength and flexural strength was observed with increasing replacement of cement. To find out compressive strength, split tensile strength and flexural strength specimens of dimensions 150x150x150mm, 150x300mm and 150x150x700mm were cast and tested as per IS 516:1959. Details of mix content with constant coarse aggregate and w/c ratio as shown in Table.

Table 3.1 Quantity of Materials as per Mix Design

\begin{tabular}{|c|c|c|c|c|c|}
\hline \multirow{2}{*}{$\begin{array}{c}\text { RHA } \\
\text { replacement }\end{array}$} & \multicolumn{3}{|c|}{ Mix Propertion (In gm) } & W/C \\
\cline { 2 - 5 } $0.5 \%$ \\
\hline $0 \%$ & C (Cement) & S (Sand) & A (Aggregate) & GP ( Glass Powder) & 0.00 \\
\hline $5 \%$ & 300 & 648 & 1360 & 0.00 & 200 \\
\hline $10 \%$ & 380 & 648 & 1360 & 20.00 & 200 \\
\hline $15 \%$ & 340 & 648 & 1360 & 40.00 & 200 \\
\hline $20 \%$ & 320 & 648 & 1360 & 60.00 & 200 \\
\hline
\end{tabular}

\subsection{COMPRESSIVE STRENGTH TEST}

Out of many test applied to the concrete, this is the utmost important which gives an idea about all the characteristics of concrete. By this single test one judge that whether Concreting has been done properly or not. For cube test two types of specimens either cubes of $15 \mathrm{~cm}$ X $15 \mathrm{~cm}$ X $15 \mathrm{~cm}$ or $10 \mathrm{~cm}$ X $10 \mathrm{~cm}$ x $10 \mathrm{~cm}$ depending upon the size of aggregate are used. For most of the works cubical moulds of size $15 \mathrm{~cm}$ x $15 \mathrm{~cm}$ x $15 \mathrm{~cm}$ are commonly used. This concrete is poured in the mould and tempered properly so as not to have any voids. After 24 hours these moulds are removed and test specimens are put in water for curing. The top surface of this specimen should be made even and smooth...These specimens are tested by compression testing machine after 7, 14 and 28 days curing. The compressive strength of concrete is the most common performance measure used in designing buildings and other structures. The compressive strength is generally measured by breaking cubical concrete specimens in a compression-testing machine. The compressive strength is calculated from the failure load divided by the cross-sectional area resisting the load

Compressive strength test results are primarily used to determine that the concrete mixture as delivered meets the requirements of the specified strength, fck in the jobs specification. The test was conducted on the cube specimen of size $150 \times 150 \times 150 \mathrm{~mm}$.

\section{Compressive Strength $=$ Failure Load $/$ Cross Sectional Area of Cube}

\subsection{SPLIT TENSILE STRENGTH}

This test method consists of applying a diametral compressive force along the length of a cylindrical concrete specimen at a rate that is within a prescribed range until failure occurs. This loading induces tensile stresses on the plane containing the applied load and relatively high compressive stresses in the area immediately around the applied load .Tensile failure occurs rather than compressive failure because the areas of load application are in a state of triaxle 


\section{International Advanced Research Journal in Science, Engineering and Technology}

Vol. 6, Issue 4, April 2019

compression, thereby allowing them to withstand much higher compressive stresses than would be indicated by a uniaxial compressive strength test result.

- Splitting tensile strength is generally greater than direct tensile strength and lower than flexural strength (modulus of rupture).

- Splitting tensile strength is used in the design of structural lightweight concrete members to evaluate the shear resistance provided by concrete and to determine the development length of reinforcement.

\section{PROCEDURE}

Marking: Draw diametral lines on each end of the specimen using a suitable device that will ensure that they are in the same axial plane

Measurements: Determine the diameter of the test specimen to the nearest $0.01 \mathrm{in}$. [0.25 $\mathrm{mm}]$ by averaging three diameters measured near the ends and the middle of the specimen and lying in the plane containing the lines marked on the two ends. Determine the length of the specimen to the nearest $0.1 \mathrm{in}$. [2 $\mathrm{mm}$ ] by averaging at least two length measurements taken in the plane containing the lines marked on the two ends.

Positioning Using Marked Diametral Lines: Center one of the plywood strips along the center of the lower bearing block. Place the specimen on the plywood strip and align so that the lines marked on the ends of the specimen are vertical and centered over the plywood strip. Place a second plywood strip lengthwise on the cylinder, centered on the lines marked on the ends of the cylinder.

Rate of Loading: Apply the load continuously and without shock, at a constant rate within the range 100 to 200 $\mathrm{psi} / \mathrm{min}[0.7$ to $1.4 \mathrm{MPa} / \mathrm{min}]$ splitting tensile stress until failure of the specimen

Calculation: Calculate the splitting tensile strength of the specimen as follows:

$$
\text { T }=\text { 2.P / I.l.d }
$$

where:

$\mathrm{T}=$ splitting tensile strength, psi [MPa]

$\mathrm{P}=$ maximum applied load indicated by the testing machine, lbf $[\mathrm{N}]$,

$\mathrm{l}=$ length, in. $[\mathrm{mm}]$, and

$\mathrm{d}=$ diameter, in. $[\mathrm{mm}]$

\subsection{FLEXURAL STRENGTH}

Flexural strength is one measure of the tensile strength of concrete. It is a measure of an unreinforced concrete beam or slab to resist failure in bending.

The test specimen shall have approximate dimensions of 6 in. x 6 in. x 20 in. (152 mm x $152 \mathrm{~mm} \times 508 \mathrm{~mm})$. The test specimen shall be kept wet until the time of the test.

I. Prepare the test specimen by filling the concrete into the mould in 3 layers of approximately equal thickness. Tamp each layer 35 times using the tamping bar as specified above. Tamping should be distributed uniformly over the entire cross section of the beam mould and throughout the depth of each layer.

II. Clean the bearing surfaces of the supporting and loading rollers, and remove any loose sand or other material from the surfaces of the specimen where they are to make contact with the rollers.

III. Circular rollers manufactured out of steel having cross section with diameter $38 \mathrm{~mm}$ will be used for providing support and loading points to the specimens. The length of the rollers shall be at least $10 \mathrm{~mm}$ more than the width of the test specimen. A total of four rollers shall be used, three out of which shall be capable of rotating along their own axes. The distance between the outer rollers (i.e. span) shall be $\mathbf{3 d}$ and the distance between the inner rollers shall be $\mathbf{d}$. The inner rollers shall be equally spaced between the outer rollers, such that the entire system is systematic.

IV. The specimen stored in water shall be tested immediately on removal from water; whilst they are still wet. The test specimen shall be placed in the machine correctly centered with the longitudinal axis of the specimen at right angles to the rollers. For moulded specimens, the mould filling direction shall be normal to the direction of loading.

V. The load shall be applied at a rate of loading of $400 \mathrm{~kg} / \mathrm{min}$ for the $15.0 \mathrm{~cm}$ specimens and at a rate of 180 $\mathrm{kg} / \mathrm{min}$ for the $10.0 \mathrm{~cm}$ specimens. 


\section{International Advanced Research Journal in Science, Engineering and Technology}

Vol. 6, Issue 4, April 2019

The Flexural Strength or modulus of rupture $\left(\mathbf{f}_{\mathbf{b}}\right)$ is given by

$$
\mathbf{f}_{\mathbf{b}}=\mathbf{p l} / \mathbf{b d}^{2} \text { (when } \mathbf{a}>20.0 \mathrm{~cm} \text { for } 15.0 \mathrm{~cm} \text { specimen or }>13.0 \mathrm{~cm} \text { for } 10 \mathrm{~cm} \text { specimen) }
$$

$\mathbf{f}_{\mathbf{b}}=\mathbf{3 p a} / \mathbf{b d}^{2}$ (when $\mathbf{a}<20.0 \mathrm{~cm}$ but $>17.0$ for $15.0 \mathrm{~cm}$ specimen or $<13.3 \mathrm{~cm}$ but $>11.0 \mathrm{~cm}$ for $10.0 \mathrm{~cm}$ specimen.)

Where,

$\mathrm{a}=$ the distance between the line of fracture and the nearer support, measured on the center line of the tensile side of the specimen

$\mathrm{b}=$ width of specimen $(\mathrm{cm})$

$\mathrm{d}=$ failure point depth $(\mathrm{cm})$

$1=$ supported length $(\mathrm{cm})$

$\mathrm{p}=\max$. Load $(\mathrm{kg})$

\section{RESULT}

Following results were obtained on designed concrete mix having specified percentage of Rice Husk Ash \& Glass Powder.

Table. 4.1 Compressive Strength Result Concrete after Replacement Of 15\% RHA

\begin{tabular}{|c|c|c|c|c|c|}
\hline Sr. No. & \multicolumn{2}{|c|}{ Replacement of Material } & 7 Days Test & 14 Days Test & 28 Days Test \\
\hline \multirow{3}{*}{} & \multirow{2}{*}{ RHA } & Glass powder & $\begin{array}{c}\text { Comp Strength } \\
\text { N/MM2 }\end{array}$ & $\begin{array}{c}\text { Comp Strength } \\
\text { N/MM2 }\end{array}$ & $\begin{array}{c}\text { Comp Strength } \\
\text { IN N/MM2 }\end{array}$ \\
\hline \multirow{3}{*}{3} & \multirow{3}{*}{$15 \%$} & $10 \%$ & 12.45 & 13.78 & 14.22 \\
\cline { 3 - 6 } & & $20 \%$ & 11.56 & 13.68 & 13.78 \\
\cline { 3 - 6 } & & $30 \%$ & 11.78 & 14.13 & 14.10 \\
\cline { 3 - 6 } & & $40 \%$ & 12.16 & 14.08 & 14.25 \\
\hline
\end{tabular}

Table. 4.2 Split Tensile Strength Result

\begin{tabular}{|c|c|c|c|c|}
\hline $\begin{array}{l}\text { Sr. } \\
\text { No. }\end{array}$ & $\begin{array}{c}\text { WGP } \\
\text { replacement }\end{array}$ & $\begin{array}{c}\text { Avg. Strength After } \\
7 \text { Days }\left(\mathrm{N} / \mathrm{mm}^{2}\right)\end{array}$ & $\begin{array}{l}\text { Avg. Strength After } \\
14 \text { Days }\left(\mathrm{N} / \mathrm{mm}^{2}\right)\end{array}$ & $\begin{array}{l}\text { Avg. Strength After } \\
28 \text { Days }\left(\mathrm{N} / \mathrm{mm}^{2}\right)\end{array}$ \\
\hline 1 & $0 \%$ & 1.10 & 1.36 & 2.25 \\
\hline 2 & $5 \%$ & 1.25 & 1.54 & 2.55 \\
\hline 2 & $10 \%$ & 1.34 & 1.69 & 2.80 \\
\hline 4 & $15 \%$ & 1.55 & 1.92 & 3.18 \\
\hline 5 & $20 \%$ & 1.58 & 2.10 & 3.29 \\
\hline
\end{tabular}

Table.4.2 Flexural Strength Result

\begin{tabular}{|c|c|c|}
\hline Sr. No. & WGP replacement & Avg. Strength After 28 Days (N/mm $\left.{ }^{2}\right)$ \\
\hline 1 & $0 \%$ & 1.57 \\
\hline 2 & $5 \%$ & 1.77 \\
\hline 2 & $10 \%$ & 1.95 \\
\hline 4 & $15 \%$ & 2.21 \\
\hline 5 & $20 \%$ & 1.96 \\
\hline
\end{tabular}




\section{International Advanced Research Journal in Science, Engineering and Technology}

Vol. 6, Issue 4, April 2019

\section{CONCLUSION}

Test result on the specimen shows there is improvement in compressive strength because of continuous increase of Rice husk ash and Glass powder. The strength increases with addition of Rice husk ash \& waste glass powder at $0 \%, 5 \%$, $10 \%$ and after that declines at $15 \%$ and $20 \%$ gradually because of more alkali silica reaction freed during hydration of cement.

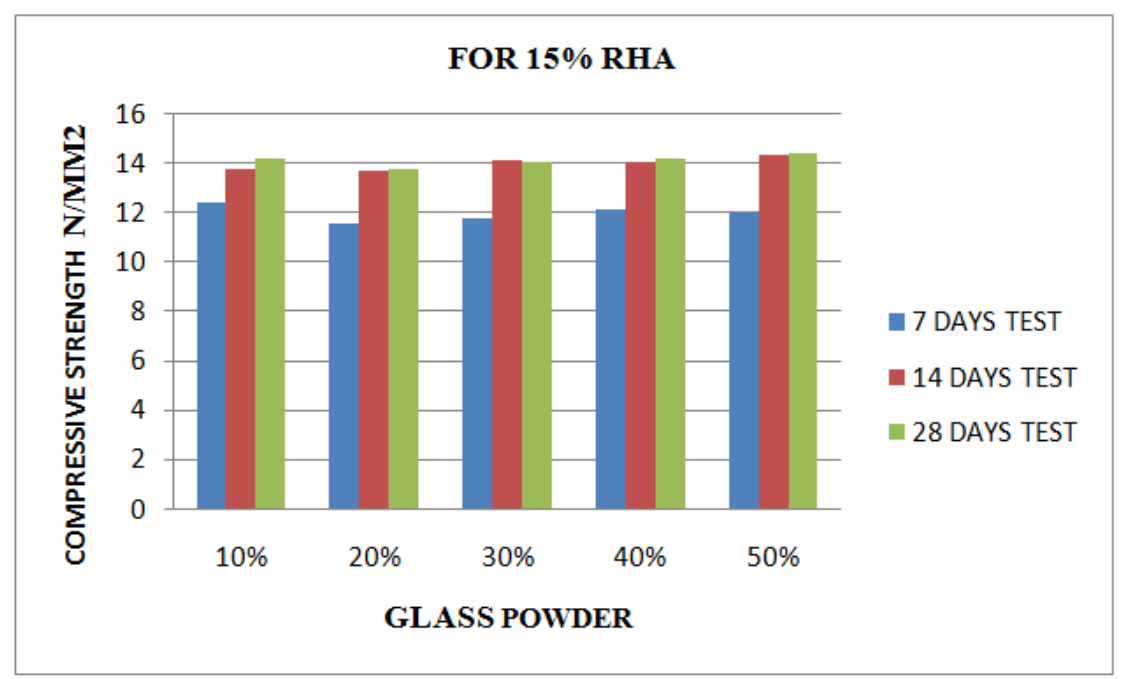

Fig. 5.1 Compressive Strength after 28 days

The aftereffects of split tensile strength of concrete mixes by partial substitution of cement by Rice husk ash \& Glass powder and utilizing of M-sand as fine aggregate was tested at 7, 14 and 28 days. Thus result tensile of concrete increases with expansion in rate of Rice husk ash \& Glass powder which can be supplanted up to $20 \%$ as indicated in graphical representation.

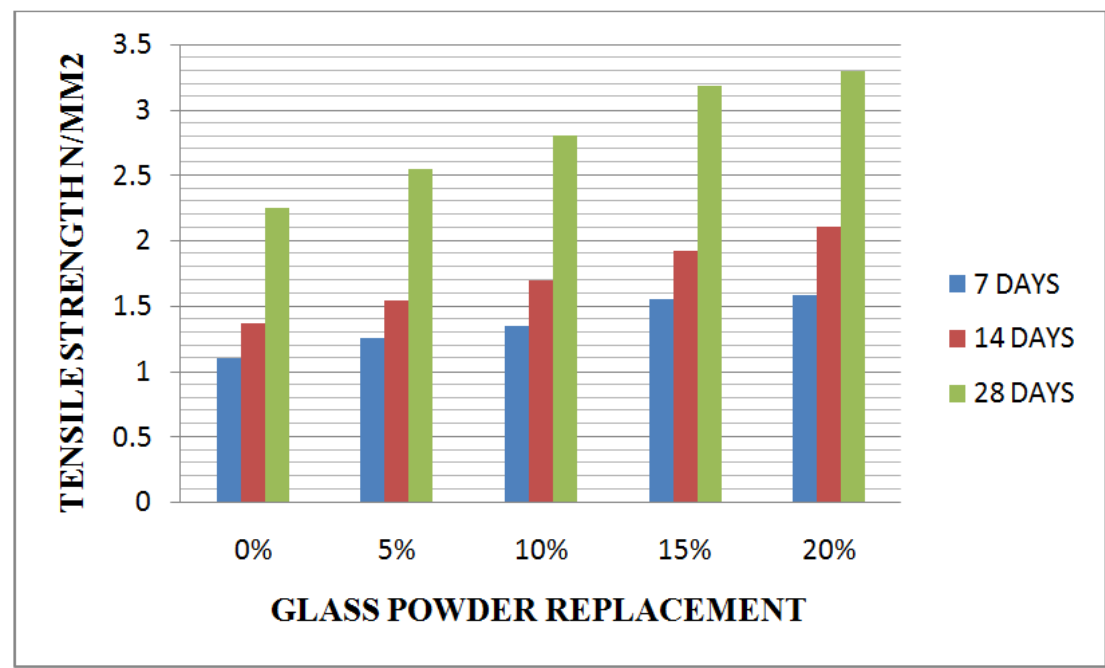

Fig. 5.2 Split Tensile Strength after 28 days

The consequences of flexural strength of concrete mix M 25 by fractional supplanting of cement with Rice husk ash Glass powder were tested at 28 and 56 days, the concrete with addition of 5\%,10\% and $15 \%$ of Rice husk ash \& Glass powder demonstrated most extreme strength when contrasted to conventional concrete. The increase in strength up to $10 \%$ replacement of cement by rice husk ash \& glass powder may be due to pozzolanic reaction of glass powder and it may be due to the rice husk ash \& glass powder effectively filling the voids and giving rise to dense concrete microstructure. However, beyond $20 \%$ the dilution effect takes over and the strength starts to drop. Thus it concludes that $20 \%$ was the optimum level for replacement of cement with rice husk ash $\&$ glass powder. 


\section{International Advanced Research Journal in Science, Engineering and Technology}

Vol. 6, Issue 4, April 2019

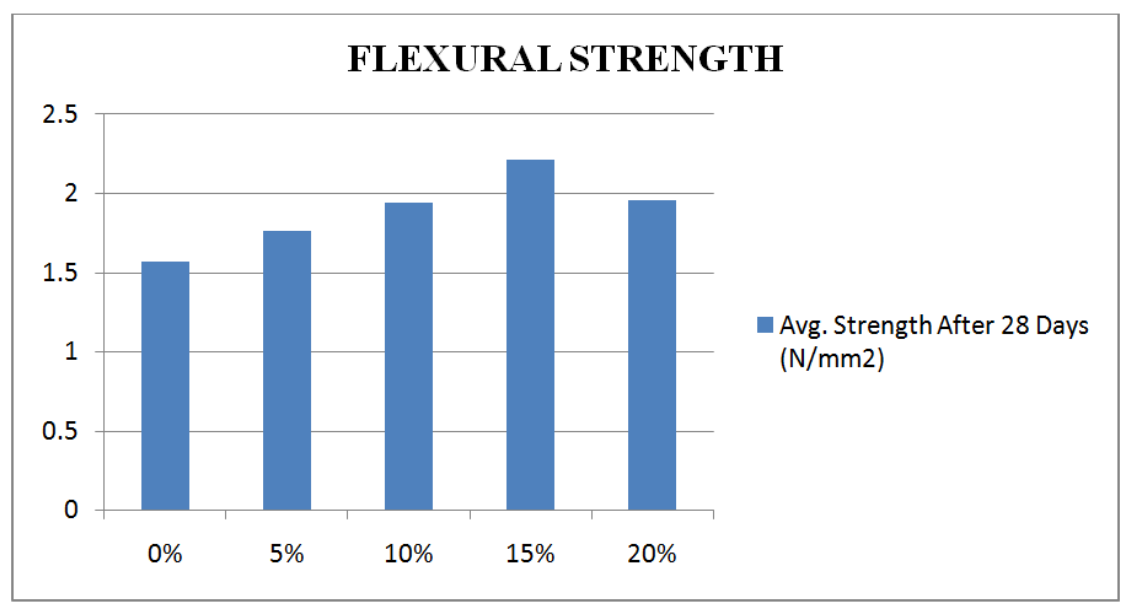

Fig. 5.3 Flexural Strength after 28 days

The increase in strength up to $15 \%$ replacement of cement by waste glass powder may be due to pozzolanic reaction of glass powder and it may be due to the glass powder effectively filling the voids and giving rise to dense concrete microstructure. However, beyond $20 \%$ the dilution effect takes over and the strength starts to drop. Thus it concludes that $20 \%$ was the optimum level for replacement of cement with glass powder.

\section{REFERENCES}

[1]. Badorul Hisham Abu Bakar, Ramadhansyah Putrajaya C and Hamidi Abdulaziz developed "Malaysian Rice Husk Ash - Improving the Durability and Corrosion Resistance of Concrete: Pre-review.

[2]. Shayan Ahmad "Value-added Utilisation of Waste Glass in Concrete" Iabse Symposium Melbourne 2002, pp. 1-11

[3]. Salek m. Seraj and salowa sultan developed "Potential of Indigenously Produced Rice Husk Ash in Concrete

[4]. 4. Cesar David Verdugo "Effect of Glass Powder on Various Properties of Concrete" International Journal of Science, Engineering and Technology, 2016, Volume 4 Issue 4, pp

[5]. Muhammad Harunur Rashid Developed "Mortar Incorporating Rice Husk Ash: Strength and Porosity" This paper presents the effects of using Rice Husk Ash (RHA) as a partial cement replacement material in mortar mixes.

[6]. omualdi, J.P. and Batson, G.B., "Mechanics of Crack Arrest in Concrete", Proceedings of ASCE, Vol.89, June 1963, pp.147-168.

[7]. Ramaswamy, "Behaviour of Fibre Concrete ", M.Tech. Thesis, IIT-Delhi, 1978

[8]. Khan, T.A.H, Laid, S.M. and Ramakrishnan, B. "Experimental Study of SFRe under Compression and Pure bending ", Journal of ACI, Vol.89, pp.96100, Feb.1972.

[9]. 9. Gabbler and Krieger, “Abrasion. Resistance of High Strength Concrete made with Class-C Flash ", ACI Journal, Nov.-Dec. 1995, pp.650655

[10]. 10.Étagère Rao.M.V. "Study of rice husk ash cement concrete as a structural material ", PhD thesis, JNTU, Hyderabad, 1992.

[11]. 11. E.B Oyetola \& M. Abdullani, "Use of rice husk ash in low cost standard concrete block production." Dept. of civil engg. Federal university of Technology, Mianna, Nigeria.

[12]. 12. Shazim Ali Memon, "Production of Low Cost Self Compacting Concrete Using Rice Husk Ash." National Institute of Technology, National University of Sciences and Technology, Pakistan.

[13]. 13. M. A. Ahmadi, O. Alidoust, I. Sadrinejad, and M. Nayeri, "Development of Mechanical Properties of Self Compacting Concrete Contain Rice Husk Ash".

[14]. 14.Jittima Prasara, "Comparative Life Cycle Assessment of Rice Husk Utilization in Thailand", M.Eng School of Global Studies, Social Science and Planning College of Design and Social Context RMIT University.

[15]. 15. Musa Alhassan and Alhaji Mohammed Mustapha, "Effect of Rice Husk Ash on Cement Stabilized Laterite", Department of Civil Engineering, Federal University of Technology, Minna, Nigeria.

[16]. 16. Vanjare and Shriram "Experimental Investigation on Self Compacting Concrete Using Glass Powder" International Journal of Engineering Research and

[17]. Applications Vol. 2, Issue 3, May-Jun 2012, pp.1488-1492

[18]. 17. Nwaubani "The Influence of Waste Glass Powder Fineness on the Properties of CemenMortars "International Journal of Application or Innovation in Engineering \& Management Volume 2, Issue 2, February 2013.

[19]. 18.Ion Dumitru, Tony Song "Field Trials Using Recycled Glass as Natural Sand Replacement and Powdered Glass as Cementitious Materials Replacement in Concrete Pavement" International Journal of Science, Engineering and Technology, 2016, Volume 6 Issue 4, pp 565-571.

[20]. 19.Ms.A.Aarthi“ Study On Glass Powder As Partial Replacement Ofcement In Concrete By Using Sillicafume” International Journal of Advanced Research Trends in Engineering and Technology (IJARTET)Vol. 3, Special Issue 2, March 2016

[21]. 20. Dr. Hassan H. Jony "The Effect of Using Glass Powder Filler on Hot Asphalt Concrete Mixtures Properties"American Journal of Engineering Research (AJER)

[22]. 21. Zainab and Enas "Use of waste glass in cement mortar" International Journal of Civil and Structural Engineering Volume 3, No 4, 2013

[23]. Volume -7, Issue-1, pp - 336-345

[24]. 22. Caijun and Keren "An Experimental Study On Waste Glass As Partial Replacement For Fine Aggregate In Concrete”International Research Journal of Engineering and Technology (IRJET) Volume: 05 Issue: 03, Mar-2018

[25]. 23. Vasudevan "Performance of Using Waste Glass Powder in Concrete as Replacement of Cement"American Journal of Engineering Research (AJER), 2013 Volume - 02, Issue -12, pp-175 - 181 